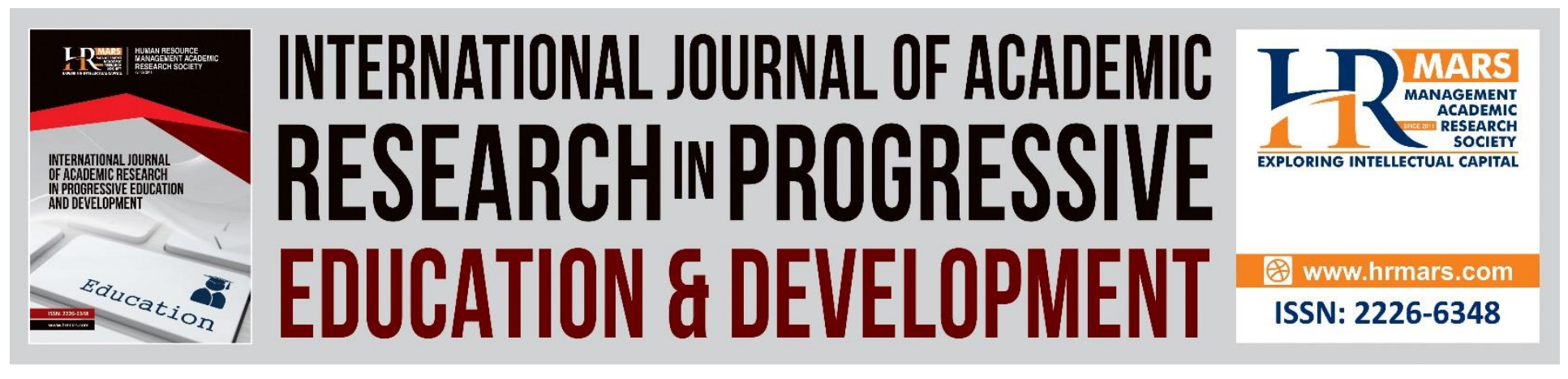

\title{
Effects of Bilingual Approach in Malay Language Teaching for Hearing Impaired Students
}

Abdul Rahim Razalli, Ardzulyna Anal, Nordin Mamat and Abdul Talib Hashim

To Link this Article: http://dx.doi.org/10.6007/IJARPED/v7-i4/4799

DOI: $10.6007 /$ IJARPED/v7-i4/4799

Received: 21 Aug 2018, Revised: 22 October 2018, Accepted: 10 Nov 2018

Published Online: 17 Nov 2018

In-Text Citation: (Razalli, Anal, Mamat, \& Hashim, 2018)

To Cite this Article: Razalli, A. R., Anal, A., Mamat, N., \& Hashim, T. (2018). Effects of Bilingual Approach in Malay Language Teaching for Hearing Impaired Students. International Journal of Academic Research in Progressive Education and Development, 7(4), 109-121.

Copyright: (C) 2018 The Author(s)

Published by Human Resource Management Academic Research Society (www.hrmars.com)

This article is published under the Creative Commons Attribution (CC BY 4.0) license. Anyone may reproduce, distribute, translate and create derivative works of this article (for both commercial and non-commercial purposes), subject to full attribution to the original publication and authors. The full terms of this license may be seen

at: http://creativecommons.org/licences/by/4.0/legalcode

Vol. 7, No. 4, 2018, Pg. 109 - 121

http://hrmars.com/index.php/pages/detail/IJARPED

JOURNAL HOMEPAGE

Full Terms \& Conditions of access and use can be found at http://hrmars.com/index.php/pages/detail/publication-ethics 


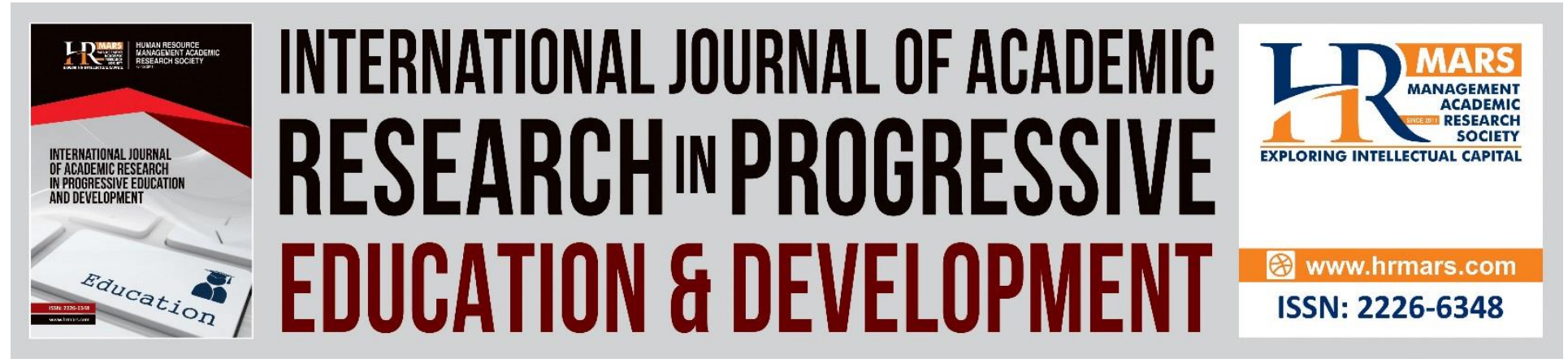

\title{
Effects of Bilingual Approach in Malay Language Teaching for Hearing Impaired Students
}

\author{
Abdul Rahim Razalli ${ }^{1}$, Ardzulyna Anal ${ }^{2}$, Nordin Mamat ${ }^{3}$ and Abdul \\ Talib Hashim ${ }^{4}$
}

Faculty of Human Development, University Pendidikan Sultan Idris.

\begin{abstract}
This study aims to identify the effects of Bilingual Approach (BA) on the teaching of Malay language for deaf student in comprehension skills and effect of deafness level to comprehension acquisition. The study was conducted through quasi-experimental comparison between the use of Bilingual Approach (Experimental Group) and the use of Manually Coded Malay (Control Group). Changes in the Malay language skills between the two groups are identified through text comprehension. The study involves 64 hearing impaired students from primary school aged 11 to 12 years as subject sample in Malaysia. There are 32 students for the Experimental Group and 32 students for the Control Group. Data for the overall skills performance were analyzed using one-way ANOVA and two-way ANOVA calculations. The findings indicate that the overall achievement for Experimental Group is significantly higher with the use of Bilingual Approach [F $\mathrm{dk}(1,63)=113.501 . p=<0.01$ ] as compared to the Control Group. The results also show significant difference between mildly deaf students and severely deaf students with the value of $t$ (63) $=13.97, p<0.05$. There is a need for more comprehensive studies to be carried out at a higher level in order to further explore the outcome of Bilingual Approach to language comprehension among students with hearing impairment.

Keywords: Bilingual Approach, Deafness Level, Comprehension, Malay Language, QuasiExperiment, Bilingual.

\section{Introduction}

First language refers to language that children learnt from birth before they get to learn a foreign language or a second language. The first language is often referred to as maternal language or mother tongue. Typically we find that the first language acquisition occurs naturally during childhood. Language acquisition at this stage usually happens gradually. Kamarudin Husin (1998) stated that the first language proficiency is not acquired through learning process but more towards indirect exposure of their maternal language. First language speakers will usually know how to use the language intuitively. Psycholinguistics view that first language is usually learnt directly without any translation effort from other languages. In this case, the children are initially
\end{abstract}


INTERNATIONAL JOURNAL OF ACADEMIC RESEARCH IN PROGRESSIVE EDUCATION AND DEVELOPMENT

Vol. 7, No. 4, 2018, E-ISSN: 2226-6348 ๑ 2018 HRMARS

competent in their speaking skill. However after some period of time as they went through listening and observation processs, they will gradually adapt to changes of their language practice. Moreover, first language learning is an indirect process and does not require formal method of learning. Mother tongue language is generally acquired as a whole and it is not learnt in separate different skills.

For deaf children to learn a Malay language is a very challenging task since it is a second language for most of them. Studies and reports by Teng Shin Min (1986), Omar Mohd Hashim (1985), Abdullah Yusof $(1992,1993,1995,1996)$ and Goh and Teh $(1990,1993)$ strongly reaffirmed the learning difficulty faced by deaf students. Their struggle in learning was also identified by their families and school teachers who are involved in Malay language teaching. Hence, both parents and teachers found it was a very demanding task to come up with effective strategy in helping the deaf students to learn the Malay language at their maximum level. Malay language is generally the medium language in schools. Failure in mastering the language would lead to their inability to grasp text comprehension and writing skills. Therefore there is a critical need for more comprehensive studies on theory, model and implementation of teaching in order to improve language limitations within the deaf children community.

People with hearing impairment usually communicate with sign language and it is considered as 'spoken' language for the deaf community. The sign language to the public refers to a type of manual-visual language, which is a signal delivered by hand and received through sight. According to Legal IDEA 1999, "to any deaf individual, native language means the mode of communication that should be used by the individual (such as sign language)". This statement supported the view that the native language of deaf children is the language which should be taught as medium of instruction for deaf children. This legislation also affirms the view and the selection of a specific mode of communication should not be in accordance with what is stipulated in the school. Currently in Malaysia, there are two main sign languages available within the deaf community namely the Malaysian Sign Language (MSL) and Manually Coded Malay (MCM). MSL is a sign language developed by deaf community by which the formation and development of MSL are greatly influenced by communication factor that reflects their daily activities and culture. Meanwhile MCM is used in teaching and learning in schools.

A new alternative to language teaching approach for deaf children is bilingual approach. Studies of bilingual-bicultural approach by Hornberger (1989) are very much related to literacy learning, bilingual-bicultural education and their impact on student bilingual literacy of deaf students and severely deaf students. He noticed that the availablity of sign language systems helped deaf students to read and write signals. Nevertheless, there are three main frameworks in the bilingual approach namely context, development and media (material) from variety perspectives of theoretical disciplines to explain the second language acquisition and bilingual education. Bilingual environment provides a background for the development of American Sign Language (ASL) as natural language and the learning of second language namely English language (written) rather than monolingual education. In a study carried out by Johnson et. al. (1989), previous curriculum content was not communicated due to dominance of the English language, 
INTERNATIONAL JOURNAL OF ACADEMIC RESEARCH IN PROGRESSIVE EDUCATION AND DEVELOPMENT

Vol. 7, No. 4, 2018, E-ISSN: 2226-6348 ๑ 2018 HRMARS

speech and/or speech medium and gesture will be communicated if ASL was used as language of instruction.

Although the MCM approach has been implemented since 1978 as a language teaching method for hearing impaired learners, their achievements are still below expectation. Based on achievement results among deaf candidates in the Primary School Achievement Test (UPSR) 2012, it was found that a total of 168 candidates obtained Grade D and E for Malay language subjects particularly in Writing and Comprehension, with 59.3 percents of failed candidates (LPM 2012). According to the statistics from the Ministry of Education (MOE), there were 7,388 deaf students from 25 schools and 73 primary and secondary integration school programs with the assistance of 927 teachers (Department of Special Education, 2005). Majority of the deaf students in Malaysia were using MCM and MSL to communicate. Sentences delivered by their gestures are usually simple and not grammatical (Elsevier, 2002). In a study conducted by the Malaysian Examinations Syndicate (LPM) in 2000, for Bahasa Melayu objective paper which was accurately answered by the deaf candidates accounted for only 29.4 per cent as compared to normal students with 58.1 percent (LPM, 2000). The difference of percentages clearly shows that deaf students are struggling to understand and answer linguistic form of questions.

Languages are developed through four stages namely listening, speaking, reading and writing. The deaf children are usually less competent in two of the four stages which are listening and speaking thus they will be using sign language. However, it is unfortunate that they are required to read (comprehension) and write in standard Malay language, thus resulted to confusion since the Sign Language and Malay Language are totally made of two different systems. Findings from a number of studies showed that deaf students performed poorly in their academic (Elsevier, 1993). The shortcoming is said to be closely linked to disability of deaf learners in mastering language proficiency since they are required to answer papers in written language. Consequently, their weakness in language proficiency caused deaf students to perform poorly in the academic field.

According to Luckner (2005), majority of the deaf students face difficulties in English reading and writing (L2). Their difficulty to master comprehension skills is basically due to their limited language acquisition during the process of teaching and learning, difficulty in understanding translated words based on sound and words contained in the text (L2) and their level of reading skills (not able to understand words and how to use them). Such problems resulted to the students unable to receive information for their reading and writing skills. Understanding word connotation English (L2) can narrow down the meaning of a word and there are a few words with positive or negative connotation for both languages, namely English and ASL (O'Grady et.al 1992).

Deaf children found it difficult to understand sign language sentences that are structured in Malay language (Asmah Omar 1981). The students are so used with the structure of their mother tongue while learning the $L 2$ language that they committed language transfer and various linguistic errors with regard to syntactic structure, inappropriate word usage in terms of semantics, unnecessary additional words, unnecessary removal of words caused by first language 
Vol. 7, No. 4, 2018, E-ISSN: 2226-6348 @ 2018 HRMARS

intrusion, i.e. sign language. Inconsistency of language structures between L1 and L2, and being unfamiliar with correct language form and structure in terms of spelling or grammar have led to confusion among the students (Roksana Bibi Abdullah 2002). The high influence of L1 can be observed especially when there is pressure in the use of L2 or when there is limited L2 environment. Dulay, Hurt and Krashen (1982) affirmed that a language learner will depend heavily on L1 before they can grasp L2 very well, which explains the tendency of deaf students to transfer L1 structure into L2 structure in producing sentences that are usually simple and ungrammatical in nature (Abdullah Yusoff, 2002).

A study by Luckner (2005) also found that the use of language teaching techniques through training, instruction in the ASL grammar principles such as translating ASL into English, discussion of stories in ASL, use of diagrams, and the use of a more comprehensive curriculum help to improve reading comprehension. Luckner (2005) also showed that ASL contains vocabulary, syntax and morphology which are different from English. As a matter of fact, the deaf students will have to master the sign language as their first language to communicate causing them more problems to master two languages at the same time. Paul (1998) found that deaf children showed poor performance in reading and text comprehension skills. They were also unable to achieve any formal competency in school. Therefore this study should be conducted to determine the level of language comprehension of deaf student with the the use of MSL and MCM in Malay language teaching. Abdullah Yusoff (2001) carried out a study on oral comprehension among deaf students on Malay language structure adapted from Rhode Island Test of Language Structure using Total Communication of MCM. The study found that deaf students hardly understand sentences that are delivered using MCM signal. Therefore, this study will look at the major effects of using texts from the Malaysian Sign Language (MSL) and Manually Coded Malay (MCM) with regard to comprehension skill of the students.

\section{Research Method}

This study adopts a quasi-experimental method using inequivalent pre-test and post-test control group. This design is to determine the effect of independent variable (teaching method) and dependent variable (comprehension test performance) without the use of random sampling for respondents' selection in both Control group and Experimental group. This experimental study uses the Pre-test and Post-test design. According to Wiersma (1991), this study was conducted using a quasi-experimental model. For the purpose of observing the effect of $2 \times 2$ factorial interactions ( 2 teaching groups $x 3$ levels of deafness), three-way ANOVA was used in this study. This research is a factorial experiment in nature (Mohd Majid 1993; Elias 1997). According to Alias (1997), factorial design is a design that allows us to study the effect of two or more factors combined simultaneously in the study. The first variable and second variable has two levels of treatment and the third variable has two levels of treatment. The use of ANOVA for data analysis is because the researchers wanted to identify the form and pattern of relationship between the independent variables and performance in Malay comprehension skill.

\section{Results}

Findings from Descriptive Statistics show the mean, standard deviation (SD) pre-test and posttest, and improved mean score for the overall performance in Experimental Group (BA) and 

DEVELOPMENT

Vol. 7, No. 4, 2018, E-ISSN: 2226-6348 @ 2018 HRMARS

Control Group (MCM). Mean for pre-test from the Experimental Group was 40.31 with 5.85 standard deviation. Mean for pre-test from the Control Group was 40.13 with 5.21 standard deviation. The findings showed a slight difference between the two groups before the treatment which was 0.18. Mean for post-test in the Experimental Group was 64.66 with 5.97 standard deviation. Mean for post-test in the Control Group was 48.88 with 5.15 standard deviation. The findings of the pre- and post-test showed significant difference between the two groups after treatment. However, both groups showed an increase in improved mean score after treatment with mean score of 64.66 for Experimental Group and 48.88 for Control Group. The findings indicate that performance in Experimental Group (mean $=24.34$ ) is much higher as compared to performance in Control Group (mean =8.75).n

Table 1.1 Mean and Standard Deviation for Pre-test, Post-test in Experimental Group and Control Group

\begin{tabular}{|l|l|l|l|l|l|l|}
\hline & \multicolumn{3}{|l|}{ Experimental Group (n=32) } & \multicolumn{3}{l|}{ Control Group (n=32) } \\
\hline Pre-Test & Post-Test & $\begin{array}{l}\text { Improved } \\
\text { Mean } \\
\text { Score }\end{array}$ & Pre-Test & Post-Test & $\begin{array}{l}\text { Improved } \\
\text { Mean } \\
\text { Score }\end{array}$ \\
\hline Mean & 40.31 & 64.66 & 24.34 & 40.13 & 48.88 & 8.75 \\
\hline $\begin{array}{l}\text { Standard } \\
\text { Deviation } \\
\text { (SD) }\end{array}$ & 5.85 & 5.97 & & 5.21 & 5.15 & \\
\hline
\end{tabular}

Table 1.2 T-test for Experimental Group and Control Group

\begin{tabular}{|l|l|l|l|l|l|l|}
\hline Group & $\mathrm{N}$ & Mean & $\mathrm{sp}$ & $\mathrm{Dk}$ & $\mathrm{t}$ & Sig. \\
\hline $\begin{array}{l}\text { Experimental } \\
\text { (BA) }\end{array}$ & 32 & 24.34 & 5.99 & 63 & 23.812 & 0.00 \\
\hline $\begin{array}{l}\text { Control } \\
\text { (MCM) }\end{array}$ & 32 & 8.75 & 4.57 & & & \\
\hline
\end{tabular}

Results on the t-test conducted on experimental and control groups showed significant differences between group of students who follow Malay language teaching using BA with students who follow the teaching of comprehension using MCM with t value $(63)=23.812, p$ $<0.05$. This means that the null hypothesis is rejected, the mean score indicates significant difference between students using BA and students using MCM approach. Students with BA method have higher mean scores than students using MCM approach. Based on t-test carried out to mildly deaf students and severely deaf students show there is significant difference between group of students with $t$ value $(63)=23.812, p<0.05$. This means that the null hypothesis is rejected. The mean score indicates significant difference to hearing loss level among the students. It was observed that severely deaf students have higher mean scores than mildly deaf students. 
Table 1.3 shows the mean, standard deviation (SD) pre-test and post-test, and improved mean score for the overall performance for Severe Hearing Loss and Mild Hearing Loss. Mean for pre-test in Severe Hearing Loss group is 37.29 with standard deviation of 4.95. Mean for Mild Hearing Loss test is 40.17 with standard deviation of 3.59. The findings show that there are differences between the two groups based on their hearing loss level before treatment which is 2.88. Mean for post-test in Severe Hearing Loss group is 56.61 with standard deviation of 4.79. Mean for post-test in Mild Hearing Loss group is 56.77 with standard deviation of 5.56. Findings from the pre-test and post-test showed that there is difference between the two hearing loss levels after the treatment. However, both groups showed an increase in the improved mean score after treatment with a mean score of 56.61 for Severe Hearing Loss and 56.77 for Mild Hearing Loss. The findings indicate that improvement in Severe Hearing Loss (mean=19.32) was much higher as compared to improvement in Mild Hearing Loss (mean=16.66).

Table 1.3 Mean and Standard Deviation for Pre-test, Post-test for Mild Deafness and Severe Deafnes

\begin{tabular}{|l|l|l|l|l|l|l|}
\hline & \multicolumn{3}{|l|}{ Experimental Group (n=32) } & \multicolumn{3}{l|}{ Control Group (n=32) } \\
\hline & Pre-Test & Post-Test & $\begin{array}{l}\text { Improved } \\
\text { Mean } \\
\text { Score }\end{array}$ & Pre-Test & Post-Test & $\begin{array}{l}\text { Improved } \\
\text { Mean } \\
\text { Score }\end{array}$ \\
\hline Mean & 37.29 & 56.61 & 19.32 & 40.17 & 56.77 & 16.66 \\
\hline $\begin{array}{l}\text { Standard } \\
\text { Deviation } \\
\text { (SD) }\end{array}$ & 4.95 & 4.79 & & 3.59 & 5.56 & \\
\hline
\end{tabular}

Table 1.4 T-Test for Mild Deafness Level and Severe Deafness Level

\begin{tabular}{lllllll}
\hline Group & $\mathrm{N}$ & Mean & sp & Dk & t & Sig. \\
\hline $\begin{array}{l}\text { Mild } \\
\text { Deafness } \\
\text { (PR) }\end{array}$ & 32 & 11.59 & 8.45 & 63 & 13.97 & 0.00 \\
$\begin{array}{l}\text { Severe } \\
\text { Deafness }\end{array}$ & 32 & 21.50 & 7.76 & & & \\
(PT) & & & & & & \\
\hline
\end{tabular}

The t-test on both deafness levels showed significant difference between mildly deaf students and severely deaf students with $t$ value $(63)=13.97, p<0.05$. This means that the null hypothesis is rejected. The mean score indicates significant difference to hearing loss levels among students. Severely deaf students have higher mean scores than mildly deaf students. 
INTERNATIONAL JOURNAL OF ACADEMIC RESEARCH IN PROGRESSIVE EDUCATION AND DEVELOPMENT

Vol. 7, No. 4, 2018, E-ISSN: $2226-6348$ @ 2018 HRMARS

\section{Discussion}

\section{Hypothesis Testing}

Hypothesis $\mathrm{H}_{\mathrm{o}}(1)$ : There is no significant difference between the Bilingual Approach (BA) as compared to the Manual Coded Malay (MCM) in the performance of Malay comprehension skills.

The ANOVA calculation on differences of the overall score was conducted for comparison of the overall performance. Results from that comparison starting with the first to the third hypothesis will be tested using MANOVA statistical inference for effect observation. The twoway variance analysis was conducted to determine the acceptance of hypotheses based on the $F$ value and degree of independence that affect the study group, as accorded by Mohd. Majid Konting, (1990). The two-way analysis of variance was used to compare the interaction of variance on the degrees of freedom in teaching method and hearing loss level towards achieving Malay proficiency skills in the experimental group and control group. Multivariate testing is used to make inferences about the three hypotheses. The significance of differences in this study was $p<0.05$. Findings of data analysis through the Multivariate calculation on the overall performance of Malay proficiency skills can be summarized in Table 1.5 below;

Table 1.5 Summary of Multivariate Test Results on Performance of Malay Proficiency Skills

\begin{tabular}{|l|l|l|l|l|l|}
\hline \multicolumn{1}{|c|}{ Variance } & \multicolumn{1}{c|}{ Multiple } & \multicolumn{1}{c|}{ df } & \multicolumn{1}{c|}{ Multiple Mean } & \multicolumn{1}{c|}{ F } & \multicolumn{1}{c|}{ Sig } \\
\hline Group & 2627.182 & 1 & 2627.182 & 113.501 & 0.000 \\
\hline Deafness Level & 306.682 & 1 & 306.682 & 13.249 & 0.000 \\
\hline Group*Deafness Level & 65.728 & 1 & 65.728 & 2.840 & 0.097 \\
\hline Error & 1388.809 & 60 & 23.147 & & \\
\hline Total & 23175.00 & 64 & & & \\
\hline
\end{tabular}

Note : $p=<0.05$

$\mathrm{dk} \quad$ : Degree of independence

Table 1.6 above clearly shows that there is a significant difference of two-way interaction teaching approach with hearing loss level on the overall comprehension performance [ $\mathrm{F}$ $\mathrm{dk}(1,64)=2.840$, with $\mathrm{p}=<0.01$ ]. Based on ratio $\mathrm{f}=2.840$, the variance analysis shows that comprehension performance in the Experimental Group [mean score for BA 24.34, standard deviation 5.99]; is higher than the Control Group [mean score for MCM 8.750, standard deviation 4:57]. This indicates that comprehension performance in the Experimental Group is higher than in the Control Group through two-way interaction with hearing loss level. Thus by setting the confidence level of $p=>0.05$, this means that the researchers have the confidence because it exceeds the expected level for $\mathrm{H}_{\mathrm{o}}(1)$ to be rejected. 
INTERNATIONAL JOURNAL OF ACADEMIC RESEARCH IN PROGRESSIVE EDUCATION AND DEVELOPMENT

Vol. 7, No. 4, 2018, E-ISSN: 2226-6348 @ 2018 HRMARS

Table 1.6 Univariate F Test Shows The Effects Of BA And MCM On Comprehension Performance

\begin{tabular}{|l|l|l|l|l|l|l|l|l|}
\hline Skill & Group & N & PM & $\begin{array}{l}\text { Error } \\
\text { SS }\end{array}$ & $\begin{array}{l}\text { Df } \\
\text { M,n }\end{array}$ & $\begin{array}{l}\text { Errof } \\
\text { MS }\end{array}$ & $\begin{array}{l}\text { F } \\
\text { value }\end{array}$ & $\begin{array}{l}\text { Palue } \\
\text { value }\end{array}$ \\
\hline \multirow{2}{*}{ Comprehension } & EG & 32 & 24.34 & 47.944 & $1 / 64$ & 2.99 & 113.501 & $0.000^{*}$ \\
\cline { 2 - 9 } & CG & 32 & 8.750 & & & & & \\
\hline
\end{tabular}

*: Significant and p value> 0.01 and 0.05 ; $^{* *}$ : Significant and p value< 0.01 ; EG:Experimental Group ;CG: Control Group;N: Number of Subject;dk :degree of independence; M: degree of independence for Experimental treatment; $\mathrm{n}$ : degree of independence for error

Hypothesis $\mathrm{H}_{\mathrm{o}}(2)$ : There is no significant difference on effects of hearing loss level on overall performance of Malay proficiency skill.

Table 1.7 below clearly shows that there is significant difference on two-way interaction teaching approach with hearing loss level on the overall comprehension performance $[F d k(1,64)=13.249$, with $p=<0.01]$. Based on the ratio $f=2.840$, variance analysis showed comprehension performance according to hearing loss level [mean score for severe deafness [mean score for severe deafness (SD) 21.50, standard deviation 7.76]; is higher than performance for mild deafness (MD) mean score 11.50, standard deviation 8.45. This indicates that comprehension performance for severe hearing loss is higher than the performance of mild hearing loss through two-way interaction teaching approach with hearing loss level. Thus by setting the confidence level of $p=>0.05$, this means that the researchers are confident because it exceeds the regulated level set for $\mathrm{Ho}_{2}$ ) to be rejected.

Table 1.7 Univariate $\mathrm{F}$ test shows effects of hearing loss level on comprehension performance

\begin{tabular}{|l|l|l|l|l|l|l|l|l|}
\hline Skill & $\begin{array}{l}\text { Level } \\
\text { Deagness }\end{array}$ & N & PM & $\begin{array}{l}\text { Error } \\
\text { SS }\end{array}$ & $\begin{array}{l}\text { Df } \\
\text { M,n }\end{array}$ & $\begin{array}{l}\text { Errof } \\
\text { MS }\end{array}$ & $\begin{array}{l}\text { F } \\
\text { value }\end{array}$ & $\begin{array}{l}\text { P } \\
\text { value }\end{array}$ \\
\hline Comprehension & EG & 21.5 & 24.34 & 47.944 & $1 / 64$ & 306.682 & 13.249 & $0.000^{*}$ \\
\cline { 2 - 9 } & CG & 11.5 & 8.750 & & & & & \\
\hline
\end{tabular}

*: Significant and $p$ value $>0.01$ and $0.05 ; * *$ : Significant and $p$ value $<0.01 ;$ EG:Experimental Group ;CG: Control Group; N: Number of Subject; dk :degree of independence; M: degree of independence for Experimental treatment; $\mathrm{n}$ : degree of independence for error.

\section{Discussion}

The main principles contained in the bilingual approach (BA) believe that language capabilities in the first language which is the mother tongue (sign language) affect the performance of second language. Thus, BA holds the principle of hypothesis on first language (L1) interdependence with second language (L2). BA showed separation of first language and second language proficiency (Separate Underlying Proficiency Model), also known as time-on-task or maximum exposure hypothesis to explain the difference between the representative language teaching should be explained through text and syntax formula. This is why language skills in BA were kept separately. There was no transfer between language and there was no basic skill that connects L1 with L2. 
INTERNATIONAL JOURNAL OF ACADEMIC RESEARCH IN PROGRESSIVE EDUCATION AND DEVELOPMENT

Vol. 7, No. 4, 2018, E-ISSN: 2226-6348 ๑ 2018 HRMARS

Thus, BA is in accordance with the research findings. Cummins (1989b) in his study observed that through a model of Common Underlying Proficiency (CUP) in which various aspects of bilingual skills in L1 and L2 are viewed as normal or interdependence between both languages. In other words, when the model is applied within bilingual education, the basic skills commonly refers to the conception of knowledge and cognitive abilities that underlie the academic performance in both languages.

The second principle in bilingual approach (BA) believes that there should be an existing first language experience (mother tongue), which promotes the development and achievement of a second language. There is one hypothesis presented by Cummins (1989 and 1991) that refers to Common Underlying Proficiency applicable in the PD approach. Regardless of the terms used, the reality of BA development research has consistently demonstrated strong relationship between language development in L1 and L2 in which both languages are interdependent. The tested BA in the teaching method was actually aligned with foreign language teaching in the United States using the CUP model. The ESL Program exists based on Separate Underlying Proficiency (SUP) model (Cummins 1989).

The Bilingual approach fully utilizes the SUP model that supports the view that language skills of learners in L1 and L2 come from different sources. If this is true, therefore the content, concepts, and skills learnt through L1 can not be transferred into L2 and vice versa. A literacy program for deaf students in Deaf Bilingual Program (DBP) will change the different function of literacy and verbal between the two languages namely English and ASL, and further strengthen literacy development for both languages. Serious consideration was given to writing that represents ASL, the first language and mother tongue of the deaf students (McIntire et al. 1987). Therefore ASL has its own "fast and easy" syntactic, semantic and pragmatic (Slobin 1985) which can be well received, analyzed and stored in the memory of students with hearing disability. Therefore, the use of MSL in BA approach as main medium of instruction in comprehension teaching is along with the notion that MSL in nature matched and is similar to ASL as accorded in the Persons with Disabilities Act 2008 and Disabilities Education Act IDEA 1999 (34C.FR 300.19, 1999) in clause .. "to any deaf individual, native language means the mode of communication that should be used by individual (such as sign language).

The findings supports a study carried out by Niederberger and Prinz (2005) on deaf students aged 8 to 17 years in Switzerland who are using sign language (mother tongue) who have demonstrated their competence in linguistics and second language writing. This study also supports another study by Hoffmiester et al. (1998), which shows positive association between ASL and reading comprehension among deaf students aged 8 to 16 years. This study is also consistent with the findings by Strong (1992), along with ASL system into English classes helped the students to improve their comprehension in both languages and English writing skills. Also findings from another study carried out by Evans (1988) through the use of ASL ( B1) in English teaching (L2), using BA have managed to increase their performance in English reading and writing skills.

The existence of sign language among deaf students has contributed to competency of Malay language as proposed by Padden and Ramsey (1998) who found significant relationship between ASL skills and English reading skills among deaf students aged between grade 4 to grade 8. Mastery of first language will affect acquisition and performance of a second language. The observation can be seen from the the result of Bahasa Melayu being considered as one of the 
Vol. 7, No. 4, 2018, E-ISSN: 2226-6348 ๑ 2018 HRMARS

school subjects that showed improvement (post-test) after treatment. Teaching of a mother tongue (L1) among deaf students require instruction on how ASL structures work similar to English grammar through the teaching of reading and writing (Padden \& Ramsey 1998; Nover \& Andrew, 1998). Studies by Liddel (1980) and Earting (1992) proposed on teaching of sign language to facilitate comprehension of reading material due to familiarity and structure appropriate to the language and culture of the deaf students. The sign language is a visual language verbalization in nature (visual-spatial).

In another study by Andrews et al. (2004), they observed that teachers often formulate a story using ASL to improve memory of the individuals who practice the ASL system. Luckner (2005) in his work was also found to apply the ASL teaching technique through ASL grammar principles such as translating ASL into English, story discussion in ASL, use of diagrams, and use of a comprehensive curriculum to improve reading comprehension. A study by Ewoldt (1985) on patterns of formed sentences in writing shows that there are some influence identified from the original language of deaf children, i.e. sign language which means children imitate sign language stories involving repetition of some verb forms.

There are significant differences between the experimental group (using BA) and the control group using MCM in which the principles hold in MCM is similar to the Manually Coded English (MCE) for simultaneous speech to increase understanding of deaf students in three ways, namely listening, speaking and signaling have shown lower performance as compared to the use of BA. These findings are supported by studies conducted by Eagney (1987) which states MCE can only help deaf students learning to read, write and socialize with people and the environment due to MCE sentence structure which is similar with English sentence structure. However, it is difficult for deaf students to transfer English language signals into writing with the right grammar and structure. Meanwhile Akamatsu and Armour (1987) addressed that deaf students may not know how to signal the written word. They may have their own vocabulary in sign language, but they could not write and read these words. The bilingual-bicultural approach believes that MCE communication should be used in English. This assertion is supported by Prinz (1998) and Paul and Quigley (1987). However, for studies like Johnson et al. (1989) and other current bilingualbicultural practitioners believe that MCE is not necessary in teaching. However, the later findings contradict with the findings of study by Prinz (1998) who proved that MCE facilitates deaf students in learning English.

\section{Corresponding Author}

Abdul Rahim Razalli, Universiti Pendidikan Sultan Idris, Malaysia,

Email: Rahim.r@fpm.upsi.edu.my

\section{References}

Yusoff, A. (1993). Struktur ayat Bahasa Melayu: satu kajian kes terhadap Pelajar pekak. Jurnal Dewan Bahasa. 37(6): 512-523

Yusoff, A. (1995). Fikiran, persekitaran dan pembentukan isyarat orang Pekak. Jurnal Dewan Bahasa 39(7): 543-552.

Yusoff, A. (2001). Kecacatan Komunikasi berkaitan dengan pendidikan, bahasa, dan kebahasaan Orang Pekak. Kuala Lumpur : Dewan Bahasa 
INTERNATIONAL JOURNAL OF ACADEMIC RESEARCH IN PROGRESSIVE EDUCATION AND DEVELOPMENT

Vol. 7, No. 4, 2018, E-ISSN: 2226-6348 @ 2018 HRMARS

Yusoff, A. (1992). Penguasaan bahasa kanak-kanak: Satu pemerhatian kes awal: Jurnal Dewan Bahasa. Kuala Lumpur. 942-954

Yusoff, A. (1994). Pembakuan bahasa isyarat dan aturannya. Jurnal Dewan Bahasa. Kuala Lumpur. 36 (6): 552-558

Yusoff, A. (1994). Komunikasi Seluruh Bahasa Malaysia Kod Tangan (BMKT): $\quad$ Bahasa komunikasi pelajar pekak.

Yusoff, A. (1993). Struktur Ayat Bahasa Melayu: Satu Kajian Kes Terhadap Pelajar Pekak dlm. Jurnal Dewan Bahasa Jun 1993 m/s 512-524.

Andrews, J.F, Leigh, I. W \& Weiner, M. I. (2004). Deaf people: Evolving perspectives from psychology, education and sosiology. USA: Allyn and Bacon.

Akamatsu, C. T., \& Armour, V. V. A. (1987). Developing Written Literacy in Deaf Children through Analyzing Sign Language. American Annals of the Deaf :132 (1) 46-51

Asmah Hj. Omar. (1981). Bahasa dan pemikiran bagi orang pekak. Jurnal Dewan Bahasa: Ogos, halaman 5-10.

Dulay, H., Hurt, M \& Krashen, S. (1982). Language Two.Oxford: Oxford Press University Eagney, P. (1987). ASL? English? Which? Comparing comprehension. American Annals of the Deaf, 132, 272-275.

Erting, C. (1992). Deafness and literacy: Why can't Sam read? Sign Language Studies,75, 97-112.

Ewoldt, C. (1987). Reading tests and the deaf reader. Perspectives for Teachers of the Hearing Impaired, 5, 21-24.

Goh Ong Sing \& The Kean Hoe (1993). Bahasa tulisan pelajar pekak: Analisis struktur sintaksis ayat berdasarkan teori tatabahasa tranformasi generatif. Dewan Bahasa dan Pustaka:Kuala Lumpur.

Hornberger, N. (1995). Creating successful learning contexts for bilingual literacy. In O. Garcia \& C. Baker (Eds.), Policy and practice in bilingual education extending the foundations (pp. 176-188). Bristol, PA: Multilingual Matters, Ltd.

Hornberger,N 1994. Metalinguistic skilla in deaf children: Knowlwedge on synonms and antonyms in ASL. Washington,DC: Gallaudet University.

Hornberger, N. (1989). Continua of biliteracy. Review of Educational Research, 39(3) 271-296.

Hoffmiester, R.J., de Villiers,P.A, Engen,E.\& Topol,D. (1998). English reading achievement and ASL skills in deaf students. Somerville, MA: Cascadilla Press. California.

Johnson, B. \& Christensen, L. (2000). Educational Research. Quatitative and Qualitative Approaches. Boston : Allyn and Bacon

Luckner, L. J. (2005). An Examination of the evidence-based literacy research in deaf education. American Annals of the Deaf 150(5):443-448.

Lembaga Peperiksaan Kementerian Pendidikan Malaysia.(2000). Laporan Prestasi PMR. Liddell, S. (1980). American Sign Language Syntax.The Hague: Mouton

Johnson, R., Liddel, S., \& Erting, C. (1989). Unlocking the curruculum: Principles for achieving access in deaf education. Washington, D.C: Gallaudet University.

Husin, K. H. (1998). Pedagogi bahasa. Petaling Jaya: Longman Malaysia Sdn.Bhd Nover, S. \& Andrews, J. (1998). Critical Pedagogy in Deaf Education: Billingual and staff development. Santa Fe, NM: New York Mexico for the deaf. 
O'Grady, W., Dobrovsky, M. \& Aronoff (1992). Semantics: The study of meaning.In C. Lucas \& C. Valli, Lingusitic of American Sign Language. Washington,D.C: Gallaudet University Press.

Niederberger, N., Prinz, P.(2005). Does the Knowledge of a natural sign language facilitate children's learning to read and write. Enfance, 4, 285-297.

Paul, P. \& Quigley, S. (2001). Language and Deafness. San Diego, CA:

Padden C., Ramsey, C., (1998). Reading ability in signinig deaf children. Topic in Language Disorder, 18(4), 30-46. Linguistics: The cambridge survey. Cambridge, England: Cambridge University Press.

Prinz, P. (1998). Forward. Topics in Language Disorder, . Journal of Speech and Hearing Research $18(4)$,v-viii.

Strong, M. (1992). Working within the billingual educatioan act. Why deaf children should not be excluded In billingual considerations in the eduacation of deaf student. Washington, D. C. Gallaudet University. 